\title{
RESPONSE OF STRUCTURAL MATERIALS TO RADIATION ENVIRONMENTS*
}

\author{
CONF-970201- - \\ C. J. Czajkowski \\ Brookhaven National Laboratory \\ Upton, NY, 11973-5000 \\ RECEIVED \\ DEC 181997 \\ USA \\ OSTI
}

\begin{abstract}
An evaluation of proton and neutron damage to aluminum, stainless stcel, nickel alloys, and various aluminum alloys has been performed. The proton studies were conducted at energies of $200 \mathrm{MeV}, 800 \mathrm{MeV}$, and $23.5 \mathrm{GeV}$. The proton studies consisted of evaluation and characterization of protonirradiated window/target materials from accelerators and comparison to nonirradiated archival materials. The materials evaluated for the proton irradiations included 99.9999 wt\% aluminum, 1100 aluminum, 5052 aluminum, 304 stainless steel, and inconel 718 . The neutron damage research centered on 6061 T-6 aluminum which was obtained from a control-rod follower from the Brookhaven National Laboratory's (BNL) High Flux Beam Reactor (HFBR). This material had received thermal neutron fluence up to $\sim 4 \times 10^{23} \mathrm{n} / \mathrm{cm}^{2}$. The possible effects of thermal-to-fast neutron flux ratios are discussed. The increases in tensile strength in the proton-irradiated matcrials is shown to be the result of atomic displacements. These displacements cause interstitials and vacancies which aggregate into defect clusters which result in radiation hardening of the materials. Production of gas (helium) in the grain boundaries of proton irradiated $99.9999 \mathrm{wt} \%$ aluminum is also discussed. The major factor contributing to the mechanical-property changes in the neutron-irradiated $6061 \mathrm{~T}-6$ aluminum is the production of transmutation products formed by interactions of the aluminum with thermal neutrons. The metallurgical and mechanicalproperty evaluations for the research consisted of electron microscopy (both scanning and transmission), tensile testing, and microhardness testing.
\end{abstract}

\section{Introduction}

This research emphasized the effects of high-energy proton (200 MeV and above) on aluminum, stainless steel, and nickel alloys and neutron damage to 6061 T-6 aluminum.

\section{Neutron Irradiations}

The Brookhaven National Laboratory (BNL) High Flux Beam Reactor (HFBR) [1,2] is a heavy-water cooled and moderated research reactor. The HFBR vessel is one entirely welded structure constructed of type 6061 T-6 aluminum. The predominant impetus for the neutron damage studies was the evaluation of the HFBR material condition [3], afier 25+ years of service.

During the time period that the HFBR was being designed, it was the common belief that fast neutrons were the principal cause of radiation-damage-induced material degradation. The available data at the time showed that $6061 \mathrm{~T}-6$ aluminum in this heat-treated condition (fully age-hardened) to be essentially unaffected by fast $(\mathrm{E}>1 \mathrm{MeV})$ fluences up to $1.2 \mathrm{x}$ $10^{21} \mathrm{n} / \mathrm{cm}^{2}[4]$.

Over the operating years, a number of specimens were removed from the HFBR for surveillance purposes. An evaluation of the data generated from these investigations indicated a number of possible phenomena occurring. The first observation was that the ductility of the $6061 \mathrm{~T}-6$ alloy appeared to reach a saturation minimum value of approximately $9 \%$ above $1.5 \times 10^{23} \mathrm{n} / \mathrm{cm}^{2}$ thermal fluence. This saturation level [3] was surmised to have occurred by a mechanism of silicon buildup without creation of a brittle phase in the grain boundary network. This silicon buildup (beyond the maximum $7 \%$ solubility maximum) was first identified by Farrell $[5,6]$ who suggested that silicon buildup could continue beyond the saturation point, after observing the silicon building up at the surfaces of internal voids in a $6061 \mathrm{~T}-6$ alloy. Since $6061 \mathrm{~T}-6$ initially contains approximately $1 \%$ magnesium (the majority of which has already reacted with the silicon during the age-hardening process), the formation of a brittle $\mathrm{Mg}_{2} \mathrm{Si}$. grain-boundary phase was considered not likely to occur. The possible role of fast-neutron fluence on the strengthening of this alloy was also evaluated during these programs. The data suggested that a high fast fluence may have the effect of randomizing the locations of the $\mathrm{Si}$ 
atoms [3] by providing pinning sites and, therefore, reduce their effect on the mechanical properties of the alloy. Thus, results obtained from this program led to the following conclusions regarding neutron damage to $6061 \mathrm{~T}-6$ in the HFBR:

1) The principal radiation effects on the aluminum is developed by the thermal neutrons' transmuting the Al to $\mathrm{Si}$.

2) The effects of radiation damage appear to saturate above $1.8 \times 10^{23} \mathrm{n} / \mathrm{cm}^{2}$ (thermal neutrons).

3) The available data generated from the analyses were insufficient to establish a minimum-ductility cut-off point.

Seven years later, another test program was initiated and a control rod follower (CRDF) was evaluated, "A-2" (A-2 designates the specific CRDF in the reactor). This investigation consisted of a more detailed study $[7,8,9,10]$ of the $6061 \mathrm{~T}-6$ alloy with microstructural detailing of radiation effects.

\section{Proton Irradiation}

The Department of Energy (DOE) in it's eflort to replace aging defense production reactors has been evaluating the possibility of using a linear proton accelerator for production of tritum. A materials test program, in support of this DOE effort, consists of evaluation and characterization of previouslyproton-irradiated stainless steel, aluminum and nickel alloy window/target materials. Evidence of materials degradation through either microstructural or mechanical-property deterioration are to be investigated and evaluated. Comparison to archive specimen mechanical/microstructural properties are performed wherever possible.

\section{Experimental Approach}

\section{Neutron Irradiation}

1. An evaluation of CRDF "A-2" (removed from the HFBR) was performed. This work consisted of transmission electron microscopy and $x$-ray diffraction studies. These tests were conducted to characterize the mechanical properties of the irradiated materials and the corresponding microstructures associated with these properties. A brief description of findings from this investigation will be discussed.

\section{Proton Irradiation}

1. 99.9999 wt\% pure aluminum which had cracked/fragmented in a $800-\mathrm{MeV}$ proton beam was evaluated. Sections of this material and nonirradiated stock from the same lot were compared. A scanning electron microscopic (SEM) examination of the fracture surfaces was made in an attempt to determine the failure mode. Standard tensile/hardness/impact tests were performed (to the extent possible) on these specirnens and compared to the archive stock available. A microstructural evaluation by TEM was performed and compared to archive material.

2. 5052 aluminum alloy available in the form of both irradiated $\left(-10^{19} \mathrm{p} / \mathrm{cm}^{2}\right.$ at $\left.200 \mathrm{MeV}, \mathrm{REF}\right)$ and unirradiated archival material were evaluated by mechanical testing/microstructural analysis. These data were compared to those in the literature. Microstructural comparisons provided a basis for material effects in a $200-\mathrm{MeV}$ proton beam.

3. Inconel windows (15) which had been irradiated in the BNL - Brookthaven Linac Isotope Producer (BLIP) - with200 $\mathrm{MeV}$ protons and had seen a current total of 23,166 $\mu \mathrm{A}$-h each. 4. A stainless-steel (Type 304) window from BLIP which had received approximately $900,000 \mu \mathrm{A}-\mathrm{h}$ of $200-\quad \mathrm{M}$ e V proton irradiation.

\section{Test Procedures}

All quantitative measurements/attribute testing were covered by ASTM standard procedures wherever possible. Metallographic techniques utilized for cutting, grinding, or polishing and were governed by "good laboratory practice". Note: all cutting of the aluminum specimens were done on an oil-cooled cutling wheel to minimize heat production.

\section{Quality Assurance}

In all cases, quantitative measurements were made with calibrated (10 NIST standards, if applicable) equipment. Written procedures governed quality related activities performed for this program. In all cases, test methods complied with (to the extent possible) national standards, ASTM/ASME, or equivalent.

\section{Results}

\section{Neutron Studies}

Evaluations performed by Oak Ridge National Laboratory [10] on specimens removed from CRDF A-2 included both chemical analyses for silicon ( $\mathrm{Si}$ ) content, transmission electron microscopy, and energy dispersive spectroscopy (EDS). These evaluations were conducted on wafers cut from the previously tested charpy impact and tensile test specimens $[7,8,9]$. These wafers were approximately $1.3 \mathrm{~mm}$ square by 0.4 mm thick.

The ORNL work' [10] noted that the noniradiated control material (6061 T-6 aluminum) consisted of equiaxed grains with some dislocations, inclusions and a fine acicular precipitate of $\mathrm{Mg}_{2} \mathrm{Si}$. Diffraction patterns from these precipitates disclosed multiple-spot arrays (characteristic of single crystals). The irradiated specimens examined also exhibited an equiaxed microstructure and some inclusions (similar in size and distribution to the unirradiated material). These inclusions were determined by EDS to consist of $\mathrm{Al}, \mathrm{Fe}, \mathrm{Si}, \mathrm{Ni}$, and $\mathrm{Cr}$. Electron diffraction patterns of these inclusions, however, were diffuse 


\section{DISCLAIMER}

This report was prepared as an account of work sponsored by an agency of the United States Government. Neither the United States Government nor any agency thereof, nor any of their employees, makes any warranty, express or implied, or assumes any legal liability or responsibility for the accuracy, completeness, or usefulness of any information, apparatus, product, or process disclosed, or represents that its use would not infringe privately owned rights. Reference herein to any specific commercial product, process, or service by trade name, trademark, manufacturer, or otherwise does not necessarily constitute or imply its endorsement, recommendation, or favoring by the United States Government or any agency thereof. The views and opinions of authors expressed herein do not necessarily state or reflect those of the United States Government or any agency thereof. 


\section{DISCLAMIER}

Portions of this docoment may be illegible in electronic image produets. Inoges are produced from the best arailable original doermenest 
rings, which indicated that the material had undergone a crystalline-to-amorphous phase transformation due to the irradiation environment. A high concentration of small, almost spherical particles, consisting primarily of silicon, was distributed throughout the grains [15]. These spherical particles replaced the original acicular $\mathrm{Mg}_{2} \mathrm{Si}$ microstructure. There was no evidence of radiation-produced voids, although there were large noncontiguous flakes, or islands, of silicon-rich phase that occupied less than one-fifth of the grain-boundary area and displayed no diffraction spots. These flakes were in evidence on almost every grain boundary examined. Additionally, at each side of grain boundaries and around inclusions, denuded areas (devoid of the spherical particles) were in evidence on the irradiated specimens examined.

The ORNL evaluations indicated the possibility that the re-ordering temperature for the amorphous silicon-rich phase coincided with the temperature of irradiation [10] "...making the conditions borderline for survival of amorphization". This question regarding the stability of the amorphous phase led to subsequent heat treatments, X-ray diffraction studies and evaluation of additional HFBR specimens (note: these data are sill being reviewed and will be presented in a subsequent paper.

\section{Proton Irradiation Data}

Tensile tests were performed on each of the various procured archival stock materials (5052 aluminum, 304 stainless

Table 2: Microhardness Test Results (KN)

Inconel 718

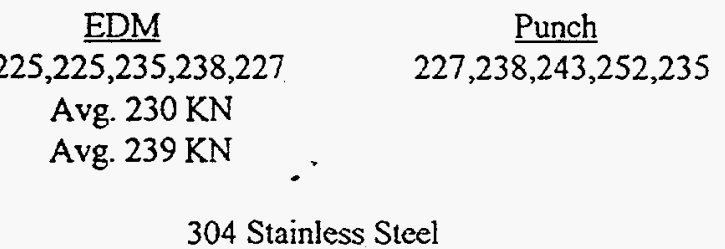

$$
\begin{array}{cc}
\text { EDM } & \text { Punch } \\
183,178,183,181,195,181 & 197,189,189,187,201 \\
\text { Avg. } 184 \mathrm{KN} & \text { Avg. } 193 \mathrm{KN} \\
5052 \mathrm{H} 24 \text { Aluminum }
\end{array}
$$

$$
\begin{array}{cc}
\stackrel{\text { EDM }}{\text { Material lost during cutting }} \begin{array}{c}
\text { Punch } \\
\text { 34.5,39.4,53.7,37.8,42.7 } \\
\text { Avg. } 41.6 \mathrm{KN}
\end{array}
\end{array}
$$

steel, and nickel alloy 718). Additionally, microhardness measurements were made on the $5052 \mathrm{H} 24$ aluminum, Microhardness measurements were performed since the irradiated materials were in the form of thin sheets and this method of testing would ensure consistency of the measured data. Table 1 lists the results of the various tensile tests performed on the archival stock. Only one specimen of the 5052 aluminum was tested.

The microhardness data for each of the archival materials is tabulated in Table 2. Two sets of microhardness values were recorded for each material.

\section{Scanning Electron Microscopy (SEM)}

The fracture faces of each of the materials tensile tested were examined by SEM. This evaluation was used to determine the mode of fracture from the uniaxial tensile pulls. Figure 1 is the low-magnification fiacture surface associated with the 304 stainless steel spocimen. The fracture was of the dimpled rupture type (Figure 2) which is typical of a ductile material failure.

Dimples are depressions in the microstructure and occur by a process of microvoid nucleation in areas of high plastic strain. Metallic inhomogeneities are preferted sites for this microvoid nucleation at grain boundaries. These microvoids grow (coalesce) as the strain increases, and finally rupture occurs, producing the dimpled rupture appearance.

\section{Transmission Electron Microscopy (TEM)}

For this project electrolytic thinning was employed using various etchants. A number of nonirradiated test specimens were thinned in order to develop the proper technique (thinning parameters) prior to use on irradiated material. After thinning, the various specimens were stored in partitioned containers and placed in designated containers. The specimens were then examined by TEM.

The stainless steel archive material was examined in the TEM. Figure 3 shows a deformation twin in the stainless steel with dislocations at the twin boundary. These microstructures are common in the 304 stainless steel, as well as the triple point (Figure 4) which was also noted in the 304 stainless archive material.

The matrix structure of the $5052 \mathrm{H} 24$ alloy was also examined by TEM (Figute 5). Various precipitates were examined with two of the typical types having been further characterized by energy-dispersive spectroscopy (EDS).

EDS is an analytical technique capable of performing elemental analysis of microvolumes, typically on the order of a few cubic microns in bulk samples and considerably less in thinner sections. 
Table I Tensile Test Results

Inconel 718

\begin{tabular}{|c|c|c|c|c|c|c|c|}
\hline $\begin{array}{c}\text { Specimen } \\
\text { Number }\end{array}$ & $\begin{array}{c}\text { Displacement } \\
\text { at Peak (in) }\end{array}$ & $\begin{array}{c}\% \text { Strain } \\
\text { at Peak (\%) }\end{array}$ & $\begin{array}{c}\text { Load at } \\
\text { Peak (lbs) } \\
\end{array}$ & $\begin{array}{c}\text { Stress at } \\
\text { Peak (psi) }\end{array}$ & $\begin{array}{c}\text { Stress at } \\
0.2 \% \text { Yicld } \\
(\mathrm{psi})\end{array}$ & $\begin{array}{l}\% \text { Strain at } \\
\text { Break (\%) } \\
\end{array}$ & $\begin{array}{c}\text { Stress at } \\
\text { Break (psi) }\end{array}$ \\
\hline 1 & 0.7370 & 58.96 & 327.4 & 131000 & 64360 & 62.48 & 126100 \\
\hline 2 & 0.7061 & 56.48 & 325.2 & 130100 & 63310 & 61.84 & 121200 \\
\hline Mean & 0.7215 & 57.72 & 326.3 & 130500 & 63840 & 62.16 & 123600 \\
\hline $\begin{array}{l}\text { Standard } \\
\text { Deviation }\end{array}$ & 0.0219 & 1.75 & 1.6 & 623. & 744. & .45 & 3479. \\
\hline
\end{tabular}

304 Stainless Sted

\begin{tabular}{|c|c|c|c|c|c|c|c|}
\hline $\begin{array}{c}\text { Specimen } \\
\text { Number }\end{array}$ & $\begin{array}{l}\text { Displacencm } \\
\text { at Pcah (III) }\end{array}$ & $\begin{array}{c}\% \text { Strain } \\
\text { at Peak (\%) }\end{array}$ & $\begin{array}{c}\text { Load at } \\
\text { Pcak (lbs) } \\
\end{array}$ & $\begin{array}{c}\text { Stress at } \\
\text { Pcak (psi) }\end{array}$ & $\begin{array}{c}\text { Stress at } \\
0.2 \% \text { Yicld } \\
\text { (psi) }\end{array}$ & $\begin{array}{l}\% \text { Strain at } \\
\text { Break (\%) }\end{array}$ & $\begin{array}{l}\text { Stress at } \\
\text { Break (psi) }\end{array}$ \\
\hline Excluded & 09611 & 76.89 & 270.6 & 130700 & 43900 & 82.49 & 96020. \\
\hline 2 & 0.9589 & 76.71 & 267.8 & 102600 & 42750 . & 84.31 & 96320. \\
\hline Excluded & 0.9481 & 75.85 & 268.6 & 102900 & 42000 & 85.61 & 98540 . \\
\hline Mean & 0.9589 & 76.71 & 267.8 & 102600 & 42883. & 84.31 & .96320 \\
\hline $\begin{array}{l}\text { Standard } \\
\text { Deviation }\end{array}$ & - & - & 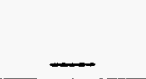 & $\ldots$ & - & - & - \\
\hline
\end{tabular}

$5052 \mathrm{H} 24$ Aluminum

\begin{tabular}{|c|c|c|c|c|c|c|c|}
\hline $\begin{array}{l}\text { Specimen } \\
\text { Number }\end{array}$ & $\begin{array}{c}\text { Displacement } \\
\text { at Peak (in) }\end{array}$ & $\begin{array}{c}\% \text { Strain } \\
\text { at Peak }(\%)\end{array}$ & $\begin{array}{c}\text { Load at } \\
\text { Peak (lbs) }\end{array}$ & $\begin{array}{r}\text { Stress at } \\
\text { Peak (psi) } \\
\end{array}$ & $\begin{array}{c}\text { Stress at } \\
0.2 \% \text { Yicld } \\
\text { (psi) }\end{array}$ & $\begin{array}{l}\% \text { Strain at } \\
\text { Break }(\%) \\
\end{array}$ & $\begin{array}{c}\text { Stress at } \\
\text { Break (psi) }\end{array}$ \\
\hline & 0.185 & - & 46.0 & 46,000 & --- & -- & - \\
\hline Mean & - & -- & - & - & - & - & - \\
\hline $\begin{array}{l}\text { Standard } \\
\text { Deviation }\end{array}$ & - & - & - & - & - & - & - \\
\hline
\end{tabular}




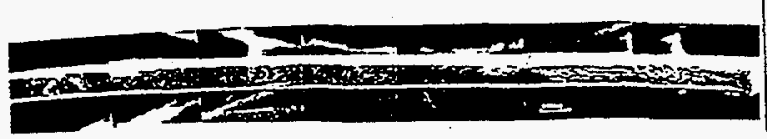

Figure 1: Lom-magnitication frackgaph of int stamkss sted

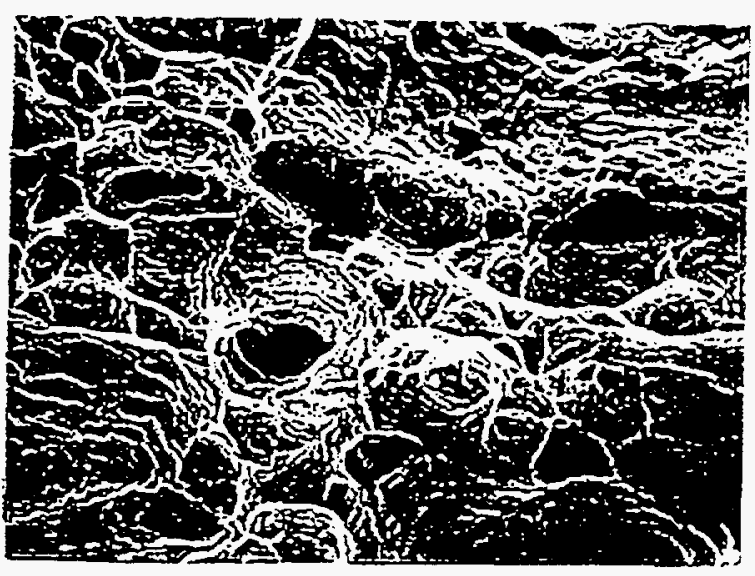

Figure 2: Higher-magnification SEM photo showing ductilefailure (typical).

Analysis of X-rays cmitted liom a sample is accomplished by crystal spoctrometers which use energy dispersive spectrometers and permit analysis by discriminating among $X$-ray eneigics. (Note: EDS will only discem elements with atomic numbers greater than $\mathrm{Na}$ so certain light elements will not be detected.) The precipitates examined by EDS wete detcmined to be primarily composed of silicon and iron.

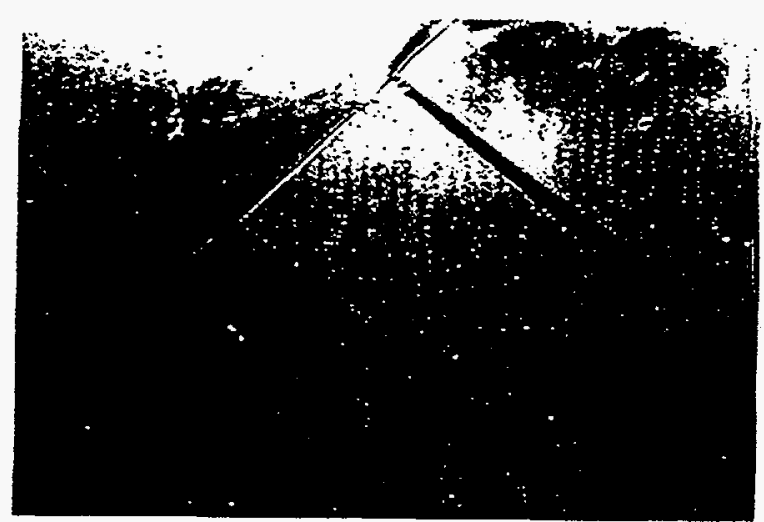

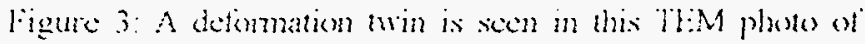
unimadialed iot stamks stcel.

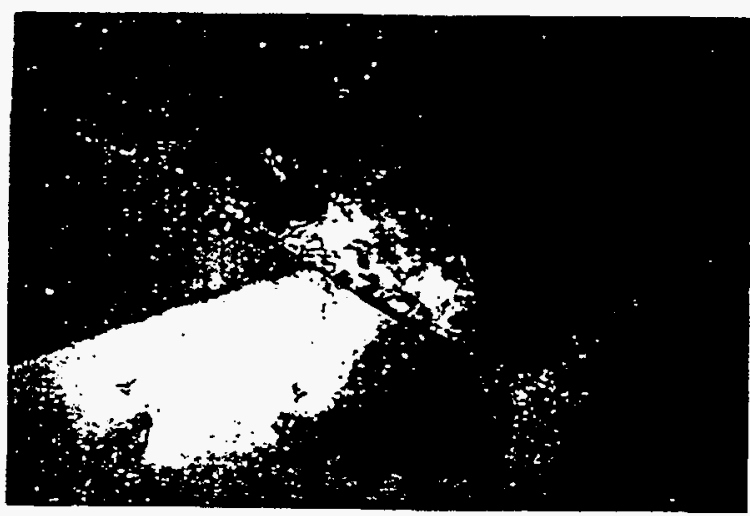

Figure 4: A triple point is seen in the austenitic matrix of the unimadialled 304 stainless sted.

Irradiated Material Examination

\section{H2+ REF Windows}

Specimens of 5052 H24 aluminum REF (Radiation Efrects Facility) windows (inadiated with $200-\mathrm{MeV}$ protons to a tluence of $\left.-2 \times 10^{14} \mathrm{p} / \mathrm{cm}^{2}\right)$ were EI $)$ machined in the shape 


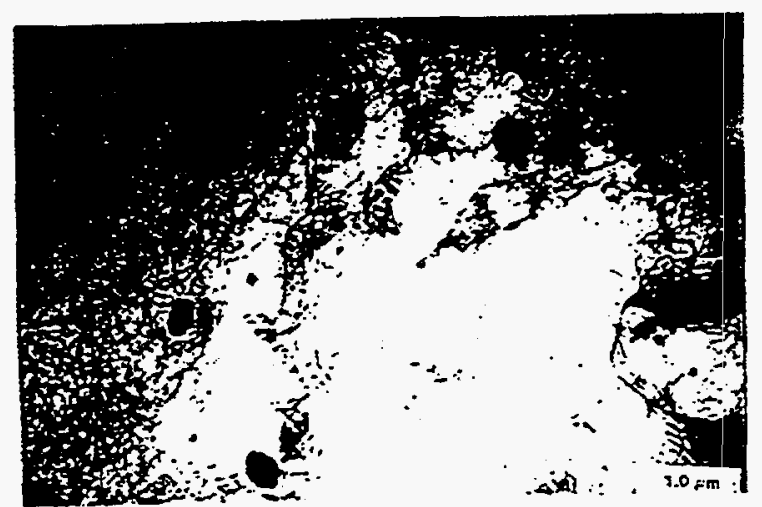

Figure 5: Matrix structure of 5052 H24 Aluminum archival stock.

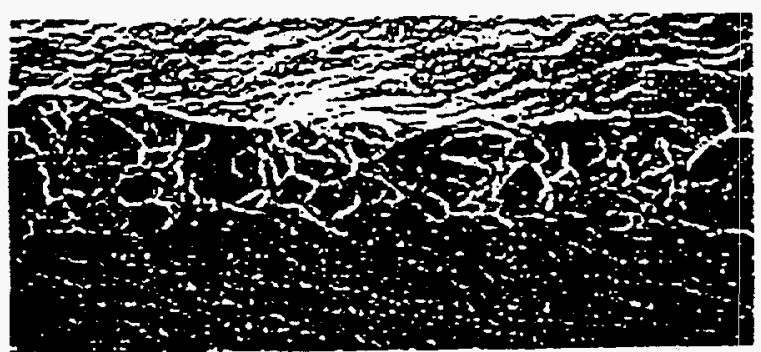

Figure 6: Fractograph of $5052 \mathrm{H} 24$ Aluminum window aticr irradiation (ductile).

of tensile specimens and then uniaxially lensile lested. Table 3 is the tabulation of these resulis. Figure 6 shows that the fracture face associalod with the inadiated $5052 \mathrm{H} 24$ aluminum is similar in appearance to those of the unirradiated archive material (i.c. ductile). This similarity in appearance is also rellected in the similar tensile strengths and elongations noted in Table 4 . There was a reduction in tensile strength $(-7 \%)$ concurrent witl a reduction in total elongation $(-9 \%)$. It is vor diflicult to take

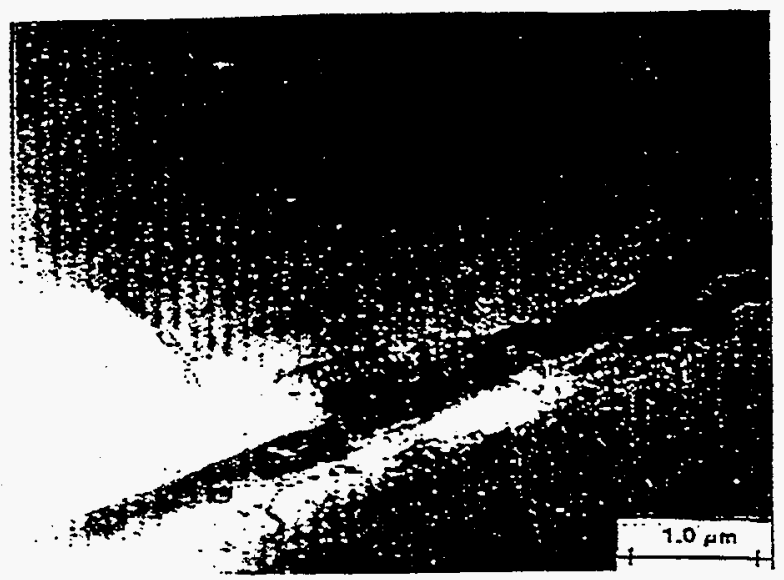

Figure 7: T1:M photo ol grain boundany in imadiated 5052

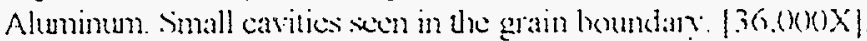

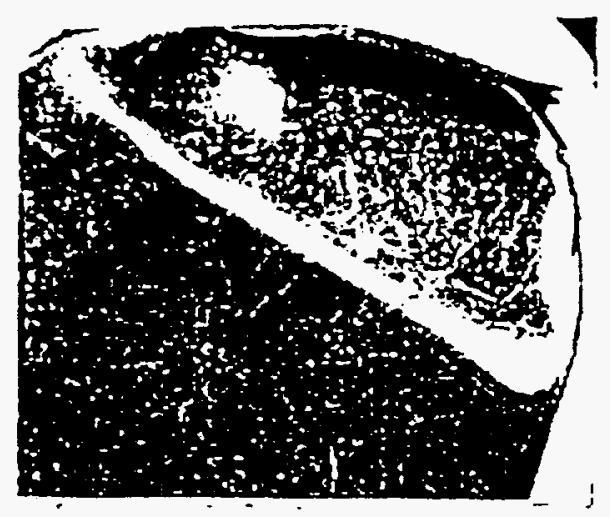

Figure 8: Damage to I3L.IP windows seen in this photograph.

these reduced values at face value without considering the very small loadings ( 19.5 and $20.9 \mathrm{~kg}$ ) needed to fracture these specimens.

TEM evaluations of the irradialed 5052 aluminum specimens disclosed some evidence of cavity and gas fomation in the grain loundaues (Figure 7). There was some evidence of dislocations in the metal matui. This possible gas fomation was the result of proton interactions with the aluminum in the $200-\mathrm{MeV}$ beam 
Table 3: Irradiated Microhardness Measurements (Avg. of 5 readings)

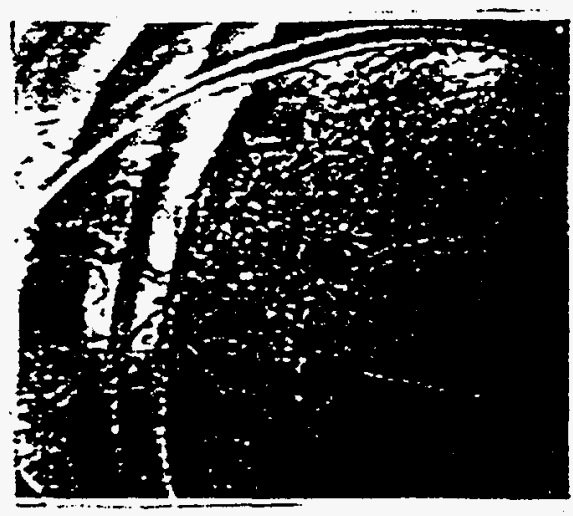

Figure 9 Cracking is cvident in this photograph of a BLIP window

\section{Brookhaven Linac Isotope Producer (BLIP) Windows}

\section{StainlessSteel and Alloy 182 Examination}

Fifleen windows ( 6 stainless steel and 9 Inconel) were obtained from the BLIP facility. The BLIP facility was first operated in 1973. It was the world's first facility to demonstrate the use of a large proton Linac to produce medical radionuclides efficiently. This production of radioisotopes was accomplished by proton spallation and lower energy reactors. The BLIP facility uses excess beam capacity from a proton Linac (200 $\mathrm{MeV}$ ) which is injected into the $33 \mathrm{MeV}$ Altemating Gradient Synchrotron (AGS). Spallation reactions produce nuclides with mass numbers less than the target.

It is evident that there was a dramatic increase in microhardness with the proton irradiations. Due to bends or cracks, specimens were unable to be machined from all windows (for this report).

Table 3 lists the microhardness readings obtained (average of 5), the flux of protons, and the corresponding unirradiated microhardness readings obtained from the previous EDM machined microhardness specimens.

The "as received" windows were in various conditions, ranging from good to poor. Good windows provided meaningful mechanical property test results because they were relatively flat and free from defects which interfered cutting. Figures 8 and 9 are photographs of two of the windows. The defects noted on these windows ranged from the window being bent, pitted, grooved and one of the windows had severe cracking in evidence. If "usable" materials were available, one tensile and

\begin{tabular}{|c|c|c|c|}
\hline $\begin{array}{c}\text { Specimen } \\
\text { I. D. }\end{array}$ & $\begin{array}{c}\text { Microhardness } \\
\text { (KN) }\end{array}$ & $\begin{array}{l}\text { Nonirradiated } \\
\text { Microhardness } \\
(\mathrm{KN}) \\
\end{array}$ & $\begin{array}{l}\text { Fluence } \\
(\mu \mathrm{A} h)\end{array}$ \\
\hline IN KQ-1 & -- & 230.0 & $28,540.8$ \\
\hline IN KQ-2 & 2276.6 & 230.0 & $28,540.8$ \\
\hline IN LI-1 & 308.0 & 230.0 & $23,166.6$ \\
\hline IN LI-2 & 319.0 & 230.0 & $23,166.6$ \\
\hline IN. JH & 317.7 & 230.0 & $10,248.4$ \\
\hline INLA-1 & -- & 230.0 & $23,166.6$ \\
\hline IN LA-2 & -- & 230.0 & $23,166.6$ \\
\hline IN LD & --- & 230.0 & $23,166.6$ \\
\hline IN KD & -.. & 230.0 & $28,540.8$ \\
\hline SS KL-1 & 267.6 & 184.0 & $3,919.5$ \\
\hline SS KL-2 & 265.1 & 184.0 & $3,919.5$ \\
\hline SS KD-1 & 302.3 & 184.0 & $6,781.1$ \\
\hline SS KD-2 & -.. & 184.0 & $6,781.1$ \\
\hline SS DH-1 & --- & 184.0 & $4,250.0$ \\
\hline SS DH-2 & ... & 184.0 & $4,250.0$ \\
\hline
\end{tabular}

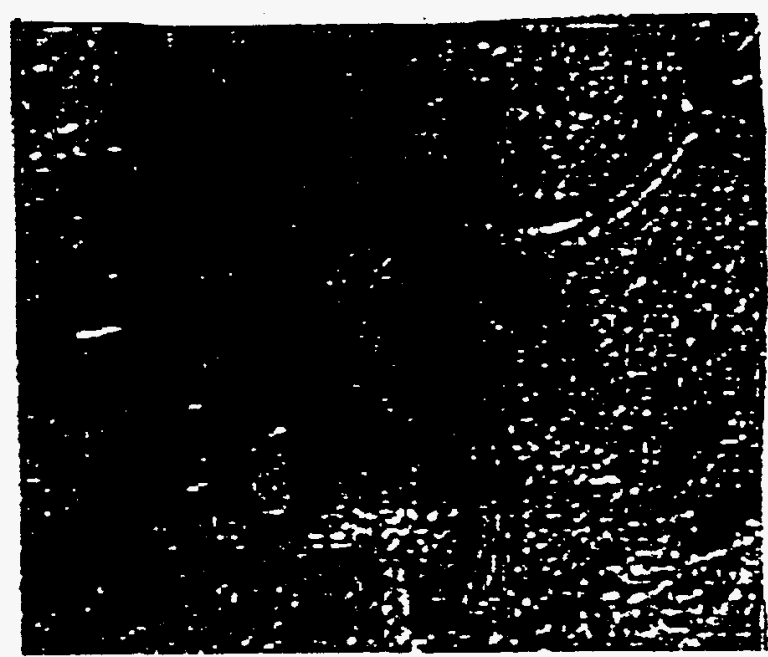

Figure 10: Specimen layout (typical) for TEM and tensile specimens.

four TEM size (Figure 10). One of the TEM slices was mounted for microhardness measurements, one was thinned for TEM examination, and two were labelled and kept for archive material. Note: The location of the area of greatest proton flux was determined by placing a photographic film (Polaroid) over 
the window and then developing it. The area of greatest activity (lightest area) determined where the EDM cuts were made.

\section{Discussion and Conclusions}

\section{Aluminum}

The 5052 aluminum material showed a reduction in tensile strength after irradiation with $200-\mathrm{MeV}$ protons. This result was considered surprising since proton irradiation would

Table 4: Results of Tensile Testing of Window Materials 5052 H24 Aluminum (0.010-cm thickness)

\begin{tabular}{ccc}
$\begin{array}{c}\text { Tensile } \\
\begin{array}{c}\text { Strength } \\
\text { (psi) }\end{array}\end{array}$ & Load (lbs.) & $\begin{array}{c}\text { Total } \\
\text { Elongation } \\
\text { (in.) }\end{array}$ \\
\hline 43,000 & 43.0 & 0.150 \\
46,000 & 46.0 & 0.165 \\
\hline
\end{tabular}

Stainless Steel (0.025-cm thickness)

$\begin{array}{lcc}\text { Tensile } & \text { Load (lbs.) } & \text { Total } \\ \text { Strength } & & \text { Elongation } \\ \text { (psi) } & & \text { (in.) }\end{array}$

\begin{tabular}{llll}
\hline Unirradiated & 108,000 & 270.0 & 0.920 \\
Unirradiated & 105,600 & 264.0 & 0.995 \\
Irradiated (KL-2) & 116,400 & 291.0 & 0.945 \\
Imadiated (KD-1) 119,200 & 298. & 0.920 \\
Irradiated (KL-1) 117,600 & 294.0 & 0.640 \\
\hline
\end{tabular}

$$
\begin{aligned}
& \text { Inconel }(0.25-\mathrm{cm} \text { thickness) } \\
& \text { Tensile } \quad \text { Load (lbs.) } \\
& \text { Strength } \\
& \text { (psi) }
\end{aligned}
$$

Total Elongation (in.)

\begin{tabular}{llll}
\hline Unirradiated & 127,200 & 318.0 & 0.695 \\
Unirradiated & 127,200 & 318.0 & 0.630 \\
Irradiated (LI-2) & 109,200 & 273.0 & 0.170 \\
Irradiated (LI-1) & 151,200 & 378.0 & 0.480 \\
Irradiated (JH) & 135,600 & 339.0 & 0.375 \\
\hline
\end{tabular}

normally increase the tensile strength of the 5052 by a displacementhardening mechanism. This phenomenon had been seen previously, however, with irradiations by $800-\mathrm{MeV}$ protons $[12,13]$. These irradiations were done at $\sim 50^{\circ} \mathrm{C}$, to doses of 0.2 dpa $\left(3.2 \times 10^{20} \mathrm{p} / \mathrm{cm}^{2}\right)$ on 6061 and 5052 cold-worked aluminum. These results were in clear disagreement with expected results for 5052 aluminum, and results on 6061 aluminum irradiated to much higher doses [14] (up to $260 \mathrm{dpa}$ ). This evaluation $[12,13]$ suggested that the main cause of the radiation-induced loss of strength was due to a loss of cold work in the 5052 material (radiation-induced), and a reduction of $\mathrm{Mg}_{2}$ $\mathrm{Si}$ precipitates in the 6061 aluminum. A dissolving of the precipitates (6061) under $800-\mathrm{MeV}$ radiation conditions at low dose was considered (by the Los Alamos researchers) to be the main cause of the softening.

This loss of cold-worked microsturucture would be a plausible explanation for the loss of strength. The original Los Alamos hypothesis $[12,13]$ of this phenomenon has since been re-evaluated (by the Los Alamos researchers). The current [15], more plausible explanation for the material softening was precipitate coursening and over-ageing due to beam heating well in excess of the anticipated temperatures. This explanation is also considered to be a distinct possibility in our study. This REF window was subjected to $200-\mathrm{MeV}$ protons withoul temperature controls or temperature monitoring. These temperatures are assumed to be sufficiently high enough to anneal out dislocations and subsequently soften the 5052 alloy.

\section{Neutron-Irradiated 6061 T-6 Aluminum}

The effects of fast-neutron displacement damage and transmutation effects in 6000 series aluminum have been cotensively investigated by various researchers $[5,16-25]$. This body of work, coupled with additional research on 99.9999 wi\% [26-33], 1100 aluminum $[46,34-40]$ and 5000 series aluminum $[41,42,43]$, make up the bulk of infomation on neutron eflects in aluminum and its alloys.

Some of the earlicst work on the effect of thermal neutrons on aluminum alloys was performed at ORNL $[33,35$, $38,40]$. These studies detcrmined that silicon is produced in aluminum through the ${ }^{27} \mathrm{Al}(\mathrm{n}, \gamma){ }^{28} \mathrm{Al},{ }^{28} \mathrm{Al}-{ }^{28} \mathrm{Si}+\beta$ reactions mostly through the interaction with thermal neutrons, and that fast neutron interactions caused the formation of dislocation loops and eventually, voids $[32,43]$.

The development of silicon-rich amorphous phases in the HFBR alloy is interesting because radiation-induced amorphization does not occur in simple metals, but is normally limited to semiconductors and ceramic compounds (e.g., Si). For the amorphous condition to exist, the temperature of irradiation must be lower than the temperature at which re-ordering of the crystal lattice atoms occurs. This re-ordering can take place at temperatures below those of bulk diffusion in the alloy. An amorphous silicon-rich phase has been previously recorded in 1100 aluminum [35]. This prior investigation reported crystalline silicon-rich precipitate particles in the matrix of 1100 aluminum with the co-existence of amorphous silicon-rich coatings around radiation induced voids. An area for future study 
would be the systematic detemination of the reordering temperature for the HFBR irradiation-produced silicon-rich phase. This exercise would entail the extaction of the amorphous precipitate phase from the bulk material. Determination of the amorphous phase mechanical properties would also be both challenging and interesting. For instance, is the phase ductile or brittle? How do it's properties compare to the crystalline phase? Questions well worth investigating if funds and programs allow.

The existence of precipitate-free zones (PFZs) in the irradiated HFBR material has been observed in over-aged nonirradiatod 6XXX aluminum [44]. The development of PFZs (after slow quenching and aging) is caused by the depletion of solute atoms near the parricles or grain boundaries and to the lack of nucleation sites caused by the migration of vacancies to particle-matrix boundaries during the quench. Grain-boundary precipitation is often accompanied by the development of PFZs [44] similar to that observed adjacent to dispersoid particles. Dispersoid particles affect quench-sensitive precipitation since they both modify the dislocation structure of the quenched material and act as nucleation sites for precipitation.

The appearance of splerical silicon-rich particles in the irradiated HFBR aluminum is interesting. One possible explanation for their shape is that they are not spherical at all, and that the TEM is not sensiluce cnough to resolve any angular facets of their construction that might be present. Another possibility for their shape is related to the aging process itself. The 6 XXX series aluminum alloys strengthen over a long period of time at room temperature This strengthening requires the formation of GP zones. Since Mg, Si may originally exist in a spherical form, radiation could be simply causing an enhanced diffusion of the precipitate bach 10 this form. This spherical form of the silicon-rich particles is probably compositionally dependent.

TEM investigations associated with a study of 5052 aluminum [32] disclosed no irradiation-induced voids in the material after a fast-neutron fluence of $1.1 \times 10^{22} \mathrm{n} / \mathrm{cm}^{2}(>0.1$ $\mathrm{MeV}$ ). Later investigations by ORNL [38] determined that irradiation-induced strengthening in 5052 aluminum was due to irradiation-produced $\mathrm{Mg}_{2} \mathrm{Si}$ precipitates. This indicated that thermal-neutron-fluence transmutation effects were the primary cause of strengthening this aluminum alloy. Further work by Farrell [42] on this alloy added additional information on the irradiation damage effects on 5052 aluminum. Farrell determined that mixed-spectrum irradiations on the 5052 at $328 \mathrm{~K}$ converts the alloy to a precipitation hardened 6000 series type alloy whose precipitates are developed by transmutation-produced silicon. It was also noted that increasing the thermal-to-fast neutron flux ratio from 1.7 to 2.1 imparted additional strengthening beyond the expectations of the silicon increase. This increased strengthening was attributed to the fineness of the irradiationinduced precipitate which was finer than that produced by thermal aging in a 6061 alloy. The increase in additional strength was surmised to be the result of higher silicon production at the 2.1 thermal/fast fuence, causing both faster production and finer $\mathrm{Mg}_{2}$ Si particles.

\section{BLIP Windows}

The irradiated windows (both stainless and Inconel), with the exception of Inconel window LI-2, all exhibited an expected increase in tensile strength with proton irradiation. Microhardness values for all of the windows lested also increased, again as expected. There were no new failure mechanisms observed on any of the windows examined. Further investigations of windows $\mathrm{LI}-2$, and $\mathrm{KL}-1$ (stainless window) will continue during the next calendar year.

\section{Aclinowledgments}

*Work supported under US DOE Contract DE-AC02$76 \mathrm{CHOOO16.}$

\section{REFERENCES}

1. Memo: Revised Fast and Thermal Fluences for Radiation Damage Estimates, P. Tichler, (April, 1985).

2. BNI-24182, Revised, HFBR Handbonk, October 1992.

3. Weeks, I.R., Czajkowski, C.I., and Tichler, P.R., ASTM 1046, Effects of Radiation on Materials: 14th International Svmposium (Vol. II), 1990, 44 1-452.

4. Graber, M.J., and Ransick, I.H., "ETR Damage Surveillance Programs, Progress Repon I", January 27, 1961.

5. Farrell, K., and King, R.T., "Tensile Properties of NeutronIradiated 6061 Aluminum Alloy in Annealed and PrecipitationHardened Conditions", ASTM STP 683, Eflects of Radiation on Structural Materials, $1979,440-449$.

6. Farrell, K., "Radiation Response of Aluminum and its Alloys After Exposure in the High Flux Isotope Reactor", Presented at AlME Annual Meeting, Chicago, IL, March 1981

7. Czajkowski, C.J., Schuster, M.H., Roberts, T.C., and Milian, L.W., "Tensile and Impact Testing of a HFBR Control Rod Follower”, BNL Informal Report BNL-43367.

8. Czajkowshi, C.J., "Fractography Evaluation of Impact and Tensile Specimens from the HFBR", BNL Informal Report BNL43602 .

9. Czajkowski, C.J, Schuster, MH., and Roberts, T.C., "Tensile Testing and Scanning Electron Microscope Examination of Charpy Impact Specimens from the HFBR", BNL Informal 
Report, BNL-43843.

10. Farrell, K., "Microstructural Appraisal of a HFBR Control Rod Follower Tube", Letter Report, February 26, 1990.

11. Weeks, J.R., Czajkow'ski, C.I., and Fartell, K., "Effects of High Thermal Neutron Fluences on Type 6061 Aluminum", ASTM STP 1175 Effects of Radiation on Materials: 16th International Svmposium, 1993, 1168-1182.

12. Singh, B.N., Lohmann, W., Ribbens, A., and Sommer, W.F., "Microstructural Changes in Commercial Aluminum Alloys Caused by Irradiation with $800-\mathrm{MeV}$ Protons", ASTM STP 955, Radiation Induced Changes in Microstructure: 13th International Symposium (Par 1), 1987, 508-519.

13. Lohmann, W., Ribbens, A., Sommer, W.F., and Singh, B.N., "Microstructure and Mechanical Properties of Medium Energy (600-800 MeV) Proton Irradiated Commercial Aluminum Alloys", Radiation Effocts, 1986, Vol. 101, 283-299.

14. Wechsler, M.S., Stubbins, J.F., Sommer, W.F., Ferguson, P.D., and Farnum, E.H., "Sclection and Qualification of Materials for the Transmutation of Waste Project", Los Alamos Report, LA-UR-92-1211, 1992.

15. Ulimaier, H., and Carsughi, F., "Radiation Damage Problems in High Power Spallation Neutron Sources", Nuclear Instruments and Methods in Physics Rescarch B 101, 1995, 406421.

16. McCoy, H.E., Jr., and Weir, J.R., Jr., "Influence of Irradiation on the Tensile Properties of the Aluminurn Alloy 6061 ", Nuclear Science and Engincering, 25, 1966, 319-327.

17. Sturcken, E.F., "Irradiation Effects in Magnesilum and Aluminum Alloys", Savannah River Laboratory Report, DP-MS78-31, 1978 .

18. Farrell, K., Long, E.L., King, R.T., and Jostons, A., "Postirradiation Examination and Testing of the ORR $N_{\mathrm{F}}$ Tray", Oak Ridge National Laboratory Report, ORNL-TM-4183, June 1973.

19. Alexander, D.J., "The Effect of Irradiation on the Mechanical Properties of 6061-T651 Aluminum", ASTM STP 1175, Effects of Radiation on Materials: 16th International Symposium, ASTM, 1993, 1151-1167.

20. Farrell, K., "Assessment of Aluminum Suuctural Materials for Service Within the ANS Reflector Vessel". Oak Ridge National Laboratory Technical Report, ORNL/TM-13049, August 1995.

21. King, R.T., Jostons, A., Farrell, K., "Neutron Irradiation Damage in a Precipitation-Hardened Aluminum Alloy", ASTM STP 529, Effects of Radiation on Substructure and Mechanical
Properties of Metals and Allovs, 1973, ASTM, 165-179.

22. Farrell, K., "New Findings in Radiation Damage in Aluminum Alloys", Presentation to the AERO Engr./Tech. Working Group, Aiken, SC, 1/16/91.

23. Farrell, K., and Richt, A.E., "Postimadiation Properties of the 6061-T6 Aluminum High Flux Isotope Reactor Hydraulic Tube", ASTM STP 570, Properties of Reactor Structural alloys after Neutron or Patticle Irradiation, ASTM, 1976, 311-325.

24. Sturken, E.F., Krapp, C.W., and Alewine, G.B., "Effects of Irradiation on 6063 Aluminum Structural Components in Savannah River Reactors", Symposium on Materials Performance in Operating Nuclear Systems, August 28-30,1973, Ames, lowa.

26. Schule, W., "Radiation-Enhanced Diftusion in FaceCentered Cubic Materials", Proccedings of the 10th International Symposium on Eflocts of Radiation on Malcrials, Savannah, GA, June 1980, 167-177.

26. Packan, N.H., "Voids in Re-Irradiated Aluminum", J. Of Nuclear Materials, 37, 1970, 251-254.

27. Packan, N.H., "Fluence and Flux Dependence of Void Formation in Pure Aluminum", I. Of Nuclcar Matcrials, 40, $1971,1-16$.

28. Wolfenden, A., "Damage in Aluminum by $200 \mathrm{kV}$ Electrons", J. Of Nuclear Materials, Letters to the Editors, 1971, 114-115.

29. Houston, J. T., and Farrell, K., "Void Coarsening in High Purity Aluminum During Postirradiation Annealing", J. Of Nuclear Materials, 40, 1971, 225-229.

30. Farrell, K., and King, R.T., "Supervoids in Irradiated Aluminum", Phys. Stat. Sol. (A) 2, KS, 1970.

31. Stiegler, J.O., Fartell, K., Dubose, C.K.H., and King, R.T., "High-Fluence Neutron-Irtadiation Damage in Aluminum", IAEA-SM-120/5-5.

32. Horsewell, A., and Singh, B.N., "Influence of Grain and Subgrain Boundaries on ' Void Formation and Growth in Aluminum Irradiated with Fast Neutrons", ASTM STP 955, Radiation-Induced Changes in Microstructure: 13 th International Symposium, 1987, 220-229.

33. Farrell, K., Wolfenden, A., and King, R.T., "The Effects of Irradiation Temperature and Preinjected Gases on Voids in Aluminum", Radiation Effects, Vol. 8, 1971, 107-114.

34. Ceresara, S., Federighi, T., and Pieragostini, F., "Recovery 
of Al-Si Alloys Neutron Irradiated at 78 Degrees K", Phys. Stat. Sol., 11, 1965, 779-787.

35. Farrell, K., Bentley, J., and Braski, D.N., "Direct Observation of Radiation-Induced Coated Cavities", Scripta Metallurgica, Vol.11, 1977, 243-248.

36. Wolfenden, A., "Effects of Preinjected Hydrogen on the Electron Displacement Damage in 1100 Aluminum", J. Of Nuclear Materials, 40, 1971, 351-352.

37. Farrell, K., and Richt, A.E., "Microstructure and Tensile Properties of Heavily Irradiated 1 100-0 Aluminum", ASTM STP 683 . Effects of Radiation on Structural Materials, 1979, 427 439.

38. Farrell, K., and King, R.T., "Radiation-Induced Strengthening and Embrittlement in Aluminum", Met. Trans., 4, May 1973, 1223-1231.

39. Jostons, A., and Long, E.L., Jr., "Radiation Damage and the Effects of Postirradiation Annealing in 1100 Grade Aluminum", Radiation Effects, Vol.16, 1972, 83-94.

40. Farrell, K, Steigler, J.O., and Gehlbach, R.E., "Transmutation-Produced Silicon Precipitates in Irradiated Aluminum," Metallography, 3, 1970, 275-284.

41. Singh, B.B., Horsewell, A., Sommer, W.F., and Lohmann, W., "Gas Accumulation at Grain Boundaries During $800-\mathrm{MeV}$ Proton Irradiation of Aluminum and Aluminum Alloys", J. Of Nuclear Materials, 141-143, 1986, 718-722.

42. Zhang, Y.G., and Jones, I.P., "Electron Irradiation of Aluminum-Zinc Alloys, 1. Radiation-Induced Segregation in an Aluminum- 0.35 at\% Zinc Alloy", J. Of Nuclear Materials, 165, $1989,252-265$.

43. Brimhall, J.L., and Master, B., "Voids in Neutron Irradiated Face Centered Cubic Metals", J. Of Nuclear Materials, 29, 123 125.

44. Aluminum:Properties and Physical Metallurgy, Edited by: Hatch, J.E., 1984, American Society for Metals.

63. Farrell, K., "Microstructure and Tensile Properties of Heavily Irradiated 5052-0 Aluminum Alloy", J. Of Nuclear Materials, 97, 1981, 33-43. 